A. Ivanchenko, orcid.org/0000-0002-1404-7278, K. Khavikova, orcid.org/0000-0002-3276-481X, A. Trukilo, orcid.org/0000-0002-5203-5948
Dniprovsk State Technical University, Kamenskoye, Ukraine, e-mail: karina.havikova@gmail.com

\title{
MATHEMATICAL MODELING OF THE PROCESSES OF WASTEWATER PURIFICATION FROM PHENOLS AND RHODANIDES USING GLAUCONITE
}

Purpose. To choose the optimal dose of the natural mineral glauconite in combination with cationic flocculant to extract phenols and rhodanides from industrial effluents. To substantiate the advantages of using natural glauconite as an adsorbent with a developed cationic ability to absorb toxic substances. To develop a mathematical model of the adsorption treatment of phenolic wastewater at a flotation plant.

Methodology. Chemical studies were carried out according to the methods of V. M. Kagasov, E. K. Derbisheva. When conducting experiments to determine the concentration of phenols in industrial effluents, a photometric method was used, based on the formation of red-colored phenol compounds with 4-aminoantipyrine in the presence of potassium hexacyanoferrate. To establish the concentration of thiocyanates in phenolic wastewater, a photometric method was used, based on the interaction of the rhodanides ion in an acidic medium with iron (III) chloride ions. The determination of the optical density of the solutions was carried out on a concentration KFK-2 photocolorimeter with subsequent use of calibration graphs.

Findings. It was experimentally shown that when applying the interval of doses of glauconite $2-6 \mathrm{~g} / \mathrm{dm}^{3}$, an effective purification of liquid waste from phenols is achieved as well as a decrease in the concentration of the initial phenolic water from 510 to 330 $390 \mathrm{mg} / \mathrm{dm}^{3}$ in the time interval of 110-140 min at the mechanical stage. A decrease in the maximum permissible concentration (MPC) of phenols in the initial wastewater of a coke chemical plant has been achieved, regulated - not more than $415 \mathrm{mg} / \mathrm{dm}^{3}$. The process of purification of industrial effluents from rhodanides with the selection of the optimal dose of adsorbent using mathematical processing of experimental data, which amounted to $2-3.5 \mathrm{~g} / \mathrm{dm}^{3}$ with flotation duration of 120 min, was studied. The initial concentration reduction of rhodanides from 475.2 to $328-348 \mathrm{mg} / \mathrm{dm}^{3}$ was obtained. The MPC of rhodanides, with a norm of not more than $400 \mathrm{mg} / \mathrm{dm}^{3}$ before biological treatment was reached.

Originality. The process of sorption removal of phenols and rhodanides from liquid wastes with different doses of glauconite to describe a mathematical model of the adsorption process was studied. For the first time, kinetic regularities of the process of phenol extraction from wastewater by glauconite in an amount of $2-8 \mathrm{~g} / \mathrm{dm}^{3}$ in combination with a cationic flocculant with a volume of $5 \mathrm{ml} / \mathrm{dm}^{3}$ in a time interval of 20-120 min were established. The opportunity to predict the optimal dose of adsorbent, to influence the time of the sorption process and reduce the content of polluting agents to environmentally friendly indicators was obtained.

Practical value. A mathematical description of the process of purification of phenolic wastewater using glauconite is given. Based on the description of the mathematical model, for industrial implementation, it is proposed to use the natural adsorbent glauconite in the optimal dose range of $2-6 \mathrm{~g} / \mathrm{dm}^{3}$ in combination with a cationic flocculant in an amount of $5 \mathrm{ml} / \mathrm{dm}^{3} \mathrm{with}$ optimal adsorption process duration of $110-140 \mathrm{~min}$.

Keywords: coke-chemical effluents, adsorption, phenols, rhodanides, natural glauconite, cationic flocculant

Introduction. Industrial wastewater, including wastewater from coke ovens, is among the most toxic sources of anthropogenic pollution $[1,2]$. The main harmful substances of this category of water - phenols, rhodanides, ammonia, resins, cyanides - adversely affect not only the environment, but also the health of employees of the enterprises and residents of the adjacent enterprises [3]. Phenolic substances are contained in the wastewater of many industrial plants in various industries during high-temperature conversion of coal, oil refining, resin and plastic production. Such aromatic hydroxyl compounds are dangerous for organisms even at low concentrations. Environmental problems caused by environmental pollution by phenols discharged from industrial wastewater are attracting wide attention of scientists because of their highly toxic effect on living and plant organisms [4]. Phenols do not have natural destructors and, through food chains, become dangerous to humans. None of the known methods can achieve (at acceptable technical and economic parameters) the required degree of purification of waste from phenols $-0.001 \mathrm{mg} / \mathrm{dm}^{3}$. Industrial phenol-containing wastewater is contaminated with other harmful substances, so more often complex methods of purification are developed, which allow preparing sewage for its reuse in production and not discharging into reservoirs.

Literature review. Phenols recovered from sewage of the chemical industry can serve as feedstock for plastics manufacturing plants and for the commercial production of resins, ep-

(C) Ivanchenko A., Khavikova K., Trukilo A., 2020 oxy resins, adhesives, plastics as structural materials in automotive and electrical engineering [5].

At modern coke plants, the total amount of phenolic water in a circulating water supply system is $0.2-0.3 \mathrm{~m}^{3}$ per 1 ton of coke. For coke extinguishing it is possible to use waste water of coke ovens. They can be cleared of mechanical impurities in horizontal wells. Sediment from sedimentation tanks, consisting of coke particles and coke sludge, is used as fuel after drying, the clarified water is used for extinguishing. For deeper water purification, flotators [6] or clarifiers [7] may be used. Phenolic compounds can be removed from wastewater by chemical oxidation, activated carbon sorption followed by regeneration, aerobic and anaerobic biodegradation, ozone oxidation, chemical coagulation. The disadvantages of most wastewater treatment methods for phenols are the long duration of the process, the cost of reagents and energy, and the high residual content of phenols in the water. The presence of concomitant contaminants such as rhodanides, resinous substances, ammonia, cyanides and others also leads to the complexity of the process of processing industrial waste of the coke industry, so the choice of an effective method for wastewater treatment is one of the important issues of modern production [3, 4].

Methods for purification of industrial effluents from low concentrations of phenols are considered developed for the paint industry. The effluents of such industries contain up to $100 \mathrm{mg} / \mathrm{dm}^{3}$ of phenols. As liquid waste, they are classified as Class V (virtually non-hazardous). However, the concentration of phenols in coke plants is much higher and refers to a hazard 
class II requiring additional purification at the mechanical stage before biochemical purification. Since the conversion of dissolved organic substances (phenols, rodanides, and others) into mineral compounds occurs at the expense of the activity of phenol- and rod-destroying microorganisms, the biological oxidation of high concentrations of contaminants leads to a toxic effect on symbiosis of active sludge $[3,8,9]$.

Critical analysis of the literature data on the study and use of dispersed sorbents and filtering materials has shown that the search for new sorption materials for the effective extraction of phenols and related substances from wastewater remains relevant $[10,11]$.

The efficiency of the sorption purification process is largely determined by the choice of the sorbent. Solid sorbents are now used as natural, artificial and synthetic materials. The adsorbents based on coal [10] find widespread use in the practice of sorption purification of aqueous media, but they are expensive material. Synthetic adsorbents are generally biodegradable and can be a source of secondary pollution of natural ecosystems. Therefore, one of the promising areas in water treatment is the use of adsorbents from natural raw materials, the advantages of which are availability, cheapness, availability of sufficient raw material resources, non-toxicity [12, 13].

The use of clay materials as adsorbents in the process of industrial wastewater treatment is becoming more widespread every year [13]. Along with the adsorbents that are traditionally used in these processes (activated carbon, zeolites, bentonites, silicates) there is a natural mineral - glauconite [3, 8]. It is a complex ecological sorbent, a mineral of the class of silicates of the group of mica hydrogens monoclinic. Glauconite is widespread in the sands, sandstones, clays, marls and limestones of all geological systems, turning these rocks greenish. Glauconite has a high porosity, a large active specific surface area and a cation exchange capacity (substitution) of isomorphic, chemical and physical nature, filtration capacity, absorption capacity of phenols, petroleum products and highly toxic substances of organic and inorganic origin. Glauconite refers to a layered silicate with a rigid structure. All the minerals in this group are characterized by the presence of only the outer adsorption surface, and their porosity is due to the gaps between the contacting particles. The specific surface area of such silicates is determined by the dispersion of the particles. The structure of the layered silicates is such that one grid of $\mathrm{Al}-$ and $\mathrm{Mg}$-octahedrons is coupled to two grids of $\mathrm{Si}-\mathrm{O}$ tetrahedrons. The main advantage of using natural glauconite adsorbent is not only complex purification of coke-chemical effluents from phenols and rhodanides, but also related substances - resins and oils, general ammonia [8].

The addition of a cationic type (flocculant) surfactant to glauconite increases the rate of flake deposition and increases the efficiency of the adsorption-flocculation process, connecting its sorbent molecules with their polymer bridges. Typically, synthetic macromolecular compounds such as polyacrylamides are used under industrial conditions. During flocculation the optimal flow of flocculant plays an important role, because at small and large doses destabilization of the dispersed system can be observed. At low concentrations of flocculant in water there are not enough macromolecules to bind the solid phase to the floccules, and at excess, a spatial grid of associated polymer molecules is formed, which impedes the convergence and aggregation of particles [8, 14]. Recycling of formed sludge with the extraction of valuable components allows their complex utilization.

Purpose. To create a mathematical model of adsorption purification of phenolic sewage by adsorption-flotation method with the help of the natural mineral of glauconite, to identify the optimal parameters of the process at which the highest degree of purification of effluents from phenols and rhodanides is achieved.

Methods. Phenolic wastewater of the site of biochemical treatment of the coke-chemical enterprise of Kamianske PJSC "YUZHKOKS" was selected as the object of the research. In the conditions of the existing coke-chemical enterprise the normative values of the quality of sewage and wastewater were approved. The approved normative content of phenols in the wastewater of the coke oven enterprise is $415 \mathrm{mg} / \mathrm{dm}^{3}$, the rhodanides $-400 \mathrm{mg} / \mathrm{dm}^{3}$; the actual concentration of $\mathrm{C}_{6} \mathrm{H}_{5} \mathrm{OH}$ (mean per year) is $962 \mathrm{mg} / \mathrm{dm}^{3}, \mathrm{SCN}^{-}$is $943 \mathrm{mg} / \mathrm{dm}^{3}$. The above data indicate that the irregularity of the biological wastewater treatment process during the year should be expected, which will lead to a negative effect of toxic substances on the symbiosis of activated sludge. In order to improve the quality of the phenolic water supplied to the aeration tanks, there is a need to refine the effluent at the mechanical stage.

In a study to determine the concentration of phenols in the source and purified effluents, a photometric method with 4-aminoantipyrine was applied, which was carried out by the standard series on a graduated graph. A photometric method based on the interaction of the rhodanide ion in acidic medium with iron (III) chloride ions was performed to determine the concentration of rhodanides in phenolic wastewater; it was carried out using a calibration graph. The optical density of the solutions on the photocalorimeter concentration KFK-2 was measured. Chemical studies were carried out according to the methods of V. M. Kagasov, E. K. Derbisheva.

Results. To solve the problem of reducing the concentration of phenols to normative values and to describe the mathematical model of the adsorption process, we created a laboratory flotation unit [6], which tested flotation. The experiment was as follows. To conduct studies on phenolic water of $0.5 \mathrm{dm}^{3}$ in flotation reactors with a volume of $1 \mathrm{dm}^{3}$, various doses of natural glauconite were added in combination with a cationic flocculant of $5 \mathrm{ml} / \mathrm{dm}^{3}$. Then, by means of a compressor, aeration of water was carried out for $20-120 \mathrm{~min}$ at an air flow rate of $0.5 \mathrm{dm}^{3} / \mathrm{min}$. Subsequently, $50 \mathrm{~cm}^{3}$ of floated sewage was selected from the upper reactor layers to determine the residual concentration of phenols and rodanides in the samples. The experiments were conducted at a temperature indicator of phenolic fluid $-20.5^{\circ} \mathrm{C}$, which corresponds to the average annual temperature of liquid waste entering the flotator. The initial concentration of phenols in the wastewater was $510 \mathrm{mg} / \mathrm{dm}^{3}$ and the rhodanides $475.2 \mathrm{mg} / \mathrm{dm}^{3}$.

In the presence of a wide range of variation of the studied parameters in the purification of phenolic effluents, it is advisable to apply the technique of planning experiments to solve the problem with the required accuracy [9]. The factors on which the degree of purification depends (residual concentration of phenols and rhodanides) are selected as follows: $X_{1}$ is glauconite dose, $\mathrm{g} / \mathrm{dm}^{3} ; X_{2}$ is time interval, $\mathrm{min} ; Y_{1}$ is the concentration of phenols, $\mathrm{mg} / \mathrm{dm}^{3} ; Y_{2}$ is the concentration of rhodanides, $\mathrm{mg} / \mathrm{dm}^{3}$.

The results of a series of laboratory experiments are summarized in Table 1, which shows the values of the initial parameters $-X_{1}, X_{2}$ and residual concentrations of phenols and rhodanides $-Y_{1}, Y_{2}$

Table 2 shows descriptive statistics of ranges of values of initial parameters and the results of experimental studies.

To identify the relationship between the parameters of the studied wastewater treatment process from phenols and rhodanides, a correlation analysis was performed, in particular the calculation of the Pearson linear correlation coefficient, confidence intervals, the hypothesis of the significance of paired correlation coefficients, the results of which are given in Table 3.

The selected correlation coefficients are significant at the level of $p<0.05000$, which determine the significant effect of the parameter $X_{2}$ (purification time interval) on the purification efficiency of both phenols and rhodanides.

Analysis of experimental data. As a result of processing the experimental data by methods of mathematical statistics, the correlation coefficients (Table 3 ) and the regression equation for the whole array of the studied variables were determined; graphs of the output parameters $\left(Y_{1}, Y_{2}\right)$ of the input $\left(X_{1}, X_{2}\right)$ in the form of graphs $Y_{1}\left(X_{1}\right)$, and the multiple regression equa- 
The values of input parameters and results of experiments

\begin{tabular}{|c|c|c|c|c|c|c|c|c|}
\hline & $X_{1}$ & $X_{2}$ & $Y_{1}$ & $Y_{1}\left(X_{1}, X_{2}\right)$ & $Y_{1}, \%$ & $Y_{2}$ & $Y_{2}\left(X_{1}, X_{2}\right)$ & $Y_{2}, \%$ \\
\hline 1 & 2 & 20 & $\mathbf{4 2 0}$ & 402.57 & 4.15 & $\mathbf{4 0 7 . 3 1 6}$ & 411.73 & 1.08 \\
\hline 2 & 2 & 40 & $\mathbf{3 8 3}$ & 380.55 & 0.64 & $\mathbf{3 9 8 . 8 3}$ & 389.75 & 2.28 \\
\hline 3 & 2 & 60 & $\mathbf{3 7 2}$ & 363.40 & 2.31 & $\mathbf{3 9 0 . 3 4 5}$ & 372.73 & 4.51 \\
\hline 4 & 2 & 120 & $\mathbf{3 2 8}$ & 341.24 & 4.04 & $\mathbf{3 2 2 . 4 5 9}$ & 351.44 & 8.99 \\
\hline 5 & 4 & 20 & $\mathbf{3 6 5}$ & 408.19 & 11.83 & $\mathbf{3 9 8 . 8 3}$ & 417.67 & 4.72 \\
\hline 6 & 4 & 40 & $\mathbf{3 8 3}$ & 383.45 & 0.12 & $\mathbf{3 9 0 . 3 4 5}$ & 394.42 & 1.04 \\
\hline 7 & 4 & 60 & $\mathbf{3 4 8}$ & 363.60 & 4.48 & $\mathbf{3 9 0 . 3 4 5}$ & 376.13 & 3.64 \\
\hline 8 & 4 & 120 & $\mathbf{3 4 8}$ & 333.32 & 4.22 & $\mathbf{3 8 1 . 8 5 9}$ & 351.02 & 8.08 \\
\hline 9 & 6 & 20 & $\mathbf{4 2 5}$ & 423.18 & 0.43 & $\mathbf{4 1 5 . 8 0 2}$ & 418.31 & 0.60 \\
\hline 10 & 6 & 40 & $\mathbf{4 2 0}$ & 395.74 & 5.78 & $\mathbf{3 8 1 . 8 5 9}$ & 393.78 & 3.12 \\
\hline 11 & 6 & 60 & $\mathbf{3 9 2}$ & 373.17 & 4.80 & $\mathbf{3 7 3 . 3 7 3}$ & 374.22 & 0.23 \\
\hline 12 & 6 & 120 & $\mathbf{3 3 5}$ & 334.77 & 0.07 & $\mathbf{3 3 9 . 4 2}$ & 345.30 & 1.73 \\
\hline 13 & 8 & 20 & $\mathbf{4 5 2}$ & 447.54 & 0.99 & $\mathbf{4 4 1 . 2 5 9}$ & 413.64 & 6.26 \\
\hline 14 & 8 & 40 & $\mathbf{4 4 0}$ & 417.39 & 5.14 & $\mathbf{3 9 0 . 3 4 5}$ & 387.85 & 0.64 \\
\hline 15 & 8 & 60 & $\mathbf{3 4 8}$ & 392.12 & 12.68 & $\mathbf{3 3 9 . 4 3}$ & 367.01 & 8.13 \\
\hline 16 & 8 & 120 & $\mathbf{3 4 8}$ & 345.59 & 0.69 & $\mathbf{3 3 9 . 4 3}$ & 334.27 & 1.52 \\
\hline & \multicolumn{2}{|l|}{ Relative error, $\%$} & 3.90 & & & 3.54 \\
\hline & \multicolumn{2}{|l|}{ Standard deviation } & 3.82 & & & 2.95 \\
\hline
\end{tabular}

Table 2

Descriptive statistics of ranges of values of initial parameters and research results

\begin{tabular}{|c|c|c|c|c|}
\hline Options & Minimum & Average & Maximum & $\begin{array}{c}\text { Standard } \\
\text { deviation }\end{array}$ \\
\hline$X_{1}$ & 2.00 & 5.00 & 8.00 & 2.31 \\
\hline$X_{2}$ & 20.00 & 60.00 & 120.00 & 38.64 \\
\hline$Y_{1}$ & 328.00 & 381.69 & 452.00 & 39.36 \\
\hline$Y_{2}$ & 322.46 & 381.33 & 441.26 & 31.82 \\
\hline
\end{tabular}

Table 3

Matrix of pairwise correlation coefficients of extraction of phenols and rhodanides from initial parameters

\begin{tabular}{|c|c|c|c|c|}
\hline & $X_{1}$ & $X_{2}$ & $Y_{1}$ & $Y_{2}$ \\
\hline$X_{1}$ & 1.000 & 0 & 0.281 & -0.0691 \\
\hline$X_{2}$ & 0 & 1.000 & -0.765 & -0.801 \\
\hline$Y_{1}$ & 0.281 & -0.765 & 1.000 & 0 \\
\hline$Y_{2}$ & -0.069 & -0.801 & 0 & 1.000 \\
\hline
\end{tabular}

tion $Y_{1}\left(X_{1}, X_{2}\right)$ are given, which are represented by graphs of $3 \mathrm{D}$ response surfaces, and graphs of $2 \mathrm{D}$ level line maps $\left(X_{1}, X_{2}\right.$, $Y_{1}$ and $X_{1}, X_{2}, Y_{2}$ ).

The obtained regression equations to determine the residual concentration of $Y_{1}$ phenols in purified water are as follows:

- for the regression equation $Y_{1}\left(X_{1}\right)$ - dependence of the residual concentration of phenols $\left(Y_{1}\right)$ in purified water on glauconite dose $\left(X_{1}\right)$

$$
Y_{1}=381.1875-6.9313 \cdot X_{1}+1.1719 \cdot X_{1}^{2} .
$$

The average relative error of the equation is $8.3 \%$ with a standard deviation of 5.03;

- for the regression equation $Y_{1}\left(X_{2}\right)$, the dependence of the residual concentration of phenols $\left(Y_{1}\right)$ in purified water on the purification time interval $\left(X_{2}\right)$ is as follows

$$
Y_{1}=451.3377-1.6703 \cdot X_{2}+0.0061 \cdot X_{2}^{2} .
$$

The average relative error of the equation is $4.69 \%$ with a standard deviation of 4.04 .

Plots of regression equation of phenol extraction $\left(Y_{1}\right.$, $\left.\mathrm{mg} / \mathrm{dm}^{3}\right)$ versus glauconite dose $\left(X_{1}, \mathrm{~g} / \mathrm{dm}^{3}\right)$ and purification time interval $\left(X_{2}\right.$, min.) are shown in Figs. 1 and 2,

According to the experiments shown in Table 1, the multiple regression equation, the dependence of the extraction of phenols $Y_{1}$ simultaneously on glauconite dose $X_{1}$ and on the interval of purification time $X_{2}$ was obtained, which has the form

$$
\begin{gathered}
Y_{1}=430.5341-2.8705 \cdot X_{1}-1.3319 \cdot X_{2}+1.1719 \cdot X_{1}^{2}- \\
-0.0677 \cdot X_{1} \cdot X_{2}+0.0061 \cdot X_{2}^{2} .
\end{gathered}
$$

The average relative error of the equation is $3.90 \%$ with a standard deviation of 3.82 .

The multiple regression equation $Y_{1}\left(X_{1}, X_{2}\right)$ (3) is represented by a graph of $3 \mathrm{D}$ response surfaces in Fig. 3 and a graph of 2D maps of the phenol extraction lines $\left(Y_{1}\right)$ depending on glauconite dose $\left(X_{1}\right)$ and the purification time interval $\left(X_{2}\right)$ shown in Fig. 4.

The graph (Fig. 4) shows that the maximum reduction of phenols $-330-350 \mathrm{mg} / \mathrm{dm}^{3}$, can be obtained at the dose values of glauconite $X_{1}\left(5.5-6 \mathrm{~g} / \mathrm{dm}^{3}\right)$ and the purification time interval of $X_{2}$ (125-140 min) corresponding to the global minimum of the surface of equation (3). However, a practical reduction of phenols $-330-390 \mathrm{mg} / \mathrm{dm}^{3}$ can be obtained at the dose values of glauconite $X_{1}\left(2-6 \mathrm{~g} / \mathrm{dm}^{3}\right)$ and the interval of purification time $X_{2}(110-140 \mathrm{~min})$, which corresponds to the economically expedient dose of glauconite $X_{1}-2 \mathrm{~g} / \mathrm{dm}^{3}$ at the duration of the experiment $X_{2}-120 \mathrm{~min}$. The quality of wastewater does not exceed the MPC of phenols - it is no more than $415 \mathrm{mg} / \mathrm{dm}^{3}$.

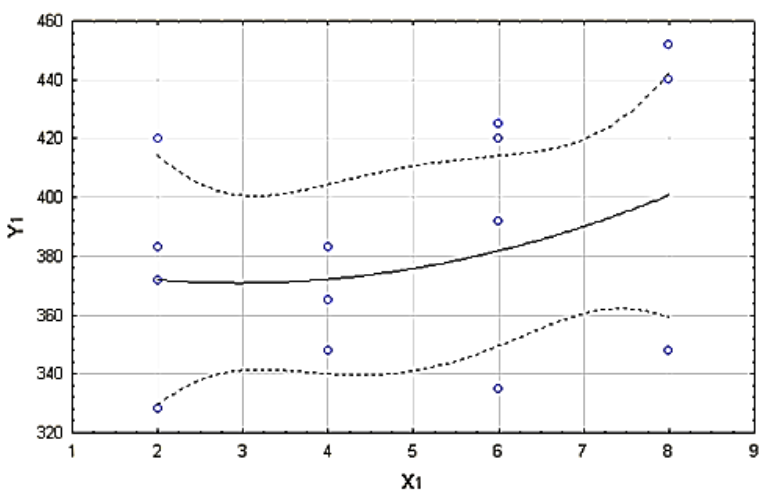

Fig. 1. Graph of dependence of extraction of phenols $Y_{1}$ on glauconite dose $X_{1}$, equation (1)

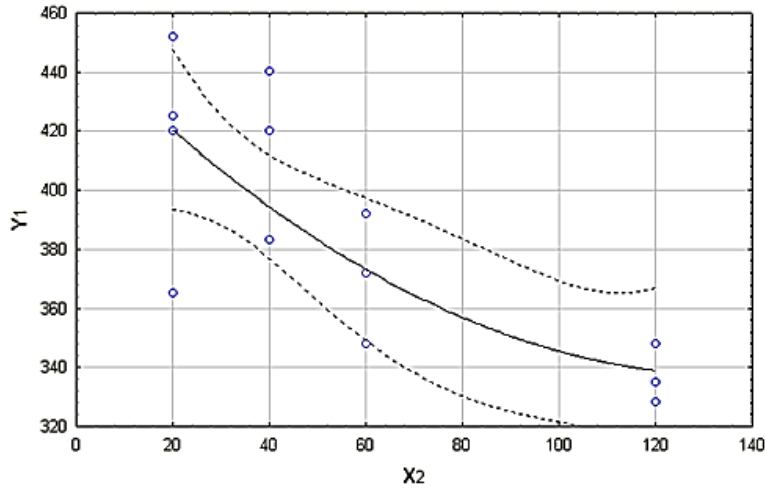

Fig. 2. Graph of dependence of extraction of phenols $Y_{1}$ on the purification time interval $X_{2}$, equation (2) 


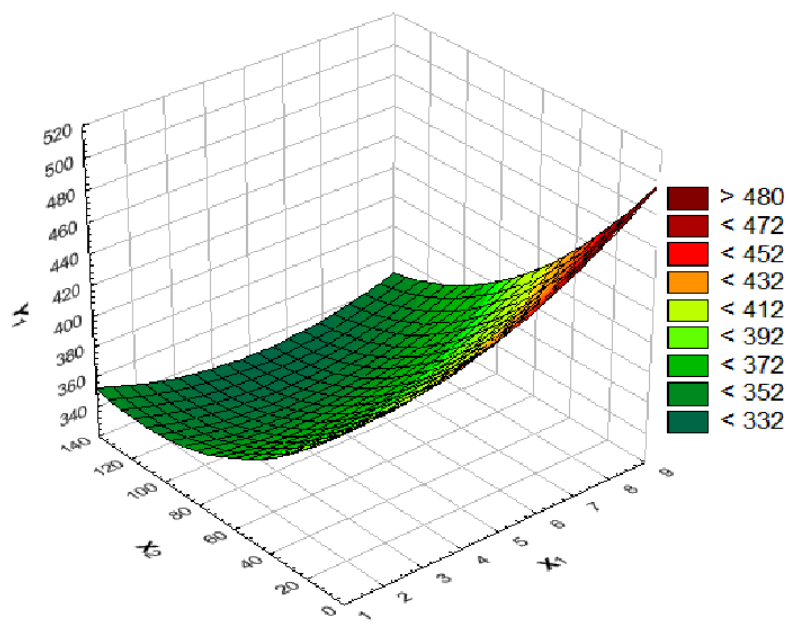

Fig. 3. Response surface for the multiple regression equation $Y_{1}\left(X_{1}, X_{2}\right)$, equation (3)

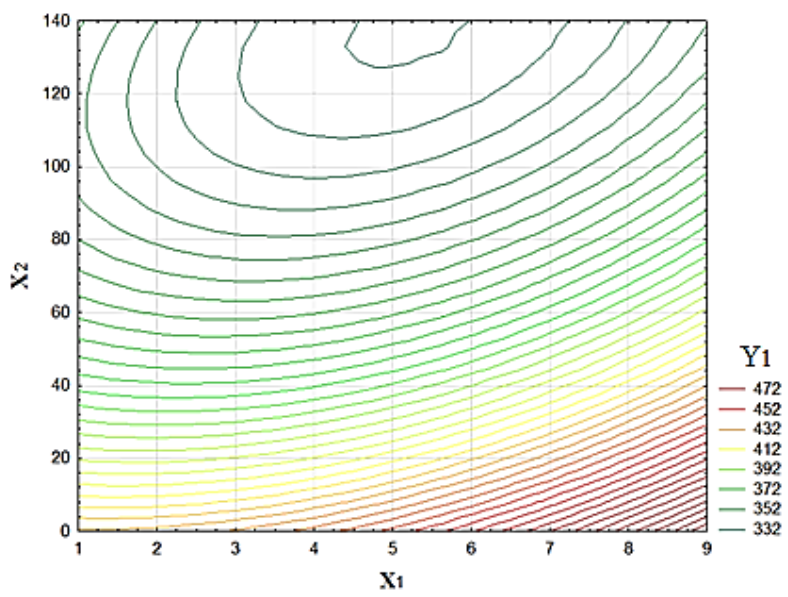

Fig. 4. Graph of dependence of extraction of phenols $Y_{1}$ on adsorbent dose $X_{1}$ and purification time $X_{2}$, equation (3)

The obtained regression equations to determine the residual concentration of $Y_{2}$ rhodanides in purified water are as follows:

- for the regression equation $Y_{2}\left(X_{1}\right)$ - dependence of residual concentration of rhodanide $\left(Y_{2}\right)$ in purified water on glauconite dose $\left(X_{1}\right)$

$$
Y_{2}=372.8459+5.6732 \cdot X_{1}-0.6628 \cdot X_{1}^{2} .
$$

The average relative error of the equation is $6.37 \%$ with a standard deviation of 5.57;

- for the regression equation $Y_{2}\left(X_{2}\right)$, the dependence of the residual concentration of $Y_{2}$ rhodanides in purified water on the purification time interval $X_{2}$ is as follows

$$
Y_{2}=444.1826-1.5664 \cdot X_{2}+0.0062 \cdot X_{2}^{2} .
$$

The average relative error of the equation is $3.52 \%$ with a standard deviation of 3.18 .

The regression equations of the dependence of rhodanide extraction $\left(Y_{2}, \mathrm{mg} / \mathrm{dm}^{3}\right)$ on glauconite dose $\left(X_{1}, \mathrm{~g} / \mathrm{dm}^{3}\right)$ and the purification time interval $\left(X_{2}, \mathrm{~min}\right)$ are shown in Figs. 5 and 6.

As can be seen from the graphs (Figs. 1, 5), increasing glauconite dose affects the efficiency of extraction of $Y_{1}$ phenols and $Y_{2}$ rodanides in the opposite way, but it indicates that the processes of sewage treatment from pollutants occur by the different mechanism. The obtained graphs (Figs. 2, 6) show that the increase in the purification time affects the efficiency of extraction of $Y_{1}$ phenols and $Y_{2}$ rodanides in the same way, that is the purification processes are similar.

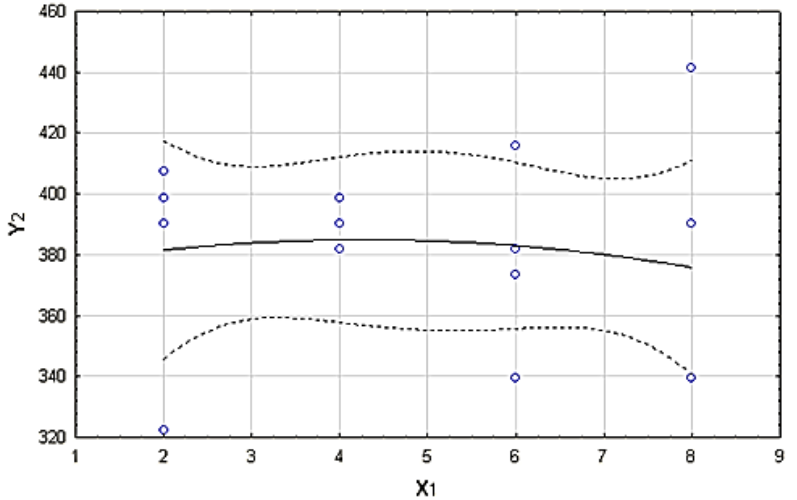

Fig. 5. Graph of dependence of extraction of rhodanide $Y_{2}$ on glauconite dose $X_{1}$, equation (4)

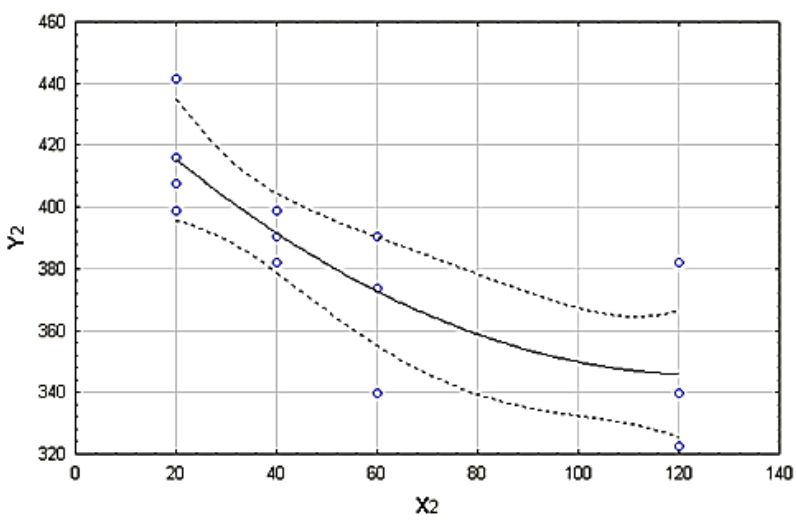

Fig. 6. Graph of dependence of extraction of rhodanides $Y_{2}$ on the purification time interval $X_{2}$ of equation (5)

According to the experiments shown in Table 1, the multiple regression equation, the dependence of the extraction of rhodanides $Y_{2}$ simultaneously on glauconite dose $X_{1}$ and on the interval of purification time $X_{2}$ was obtained, which has the form

$$
\begin{gathered}
Y_{2}=426.1521+7.5829 \cdot X_{1}-1.4073 \cdot X_{2}-0.6628 \cdot X_{1}^{2}- \\
-0.0318 \cdot X_{1} \cdot X_{2}+0.0062 \cdot X_{2}^{2} .
\end{gathered}
$$

The average relative error of the equation is $3.54 \%$ with a standard deviation of 2.95

The multiple regression equation $Y_{2}\left(X_{1}, X_{2}\right)(6)$ is represented by a graph of 3D response surfaces in Fig. 7 and a graph of 2D maps of the lines of extraction of rhodanides $\left(Y_{2}\right)$, depending on glauconite dose $\left(X_{1}\right)$ and the time interval of purification $\left(X_{2}\right)$, which are shown in Fig. 8.

The graph (Fig. 8) shows that the maximum reduction of rhodanide to $328-348 \mathrm{mg} / \mathrm{dm}^{3}$ can be obtained with the maximum dose of $X_{1}$ glauconite $\left(2-3.5 \mathrm{~g} / \mathrm{dm}^{3}\right)$ and the minimum $X_{2}$ purification time interval $(120 \mathrm{~min})$ corresponding to the saddle point of the surface of equation (6). The quality of the purified phenolic effluent complies with the current standards (MPC of rhodanides not more than $400 \mathrm{mg} / \mathrm{dm}^{3}$ ). The optimal contact time of the sorbent with the liquid waste is $120 \mathrm{~min}$, which does not exceed the residence time of wastewater in the flotator and meets the technological requirements.

As a result of the studies and their mathematical processing, it should be noted that the spent natural adsorbent after phenols and rhodanides extraction from coke-chemical wastewater does not require regeneration, since its further use as a binding additive to asphalt concrete mixtures is proposed.

Conclusions. Based on the experimental data, regression equations were obtained to determine the residual concentration of phenols and rhodanides depending on glauconite dose and the time of contact of the adsorbent with wastewater. 


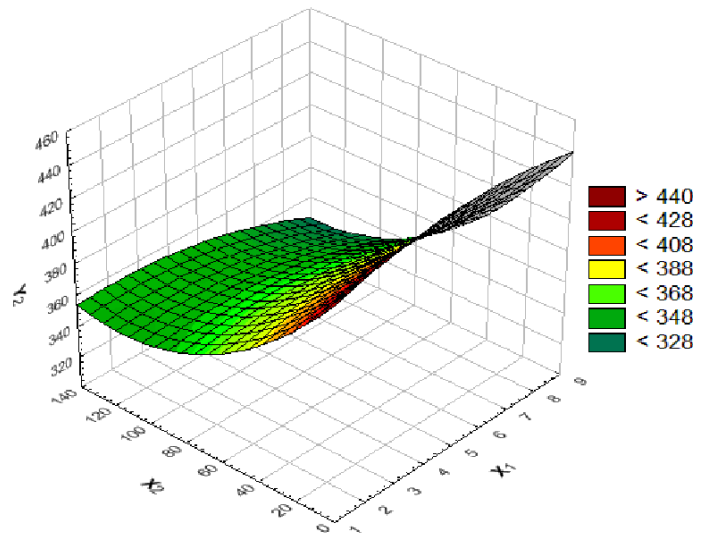

Fig. 7. Response surface for the multiple regression equation $Y_{2}\left(X_{1}, X_{2}\right)$, equation (6)

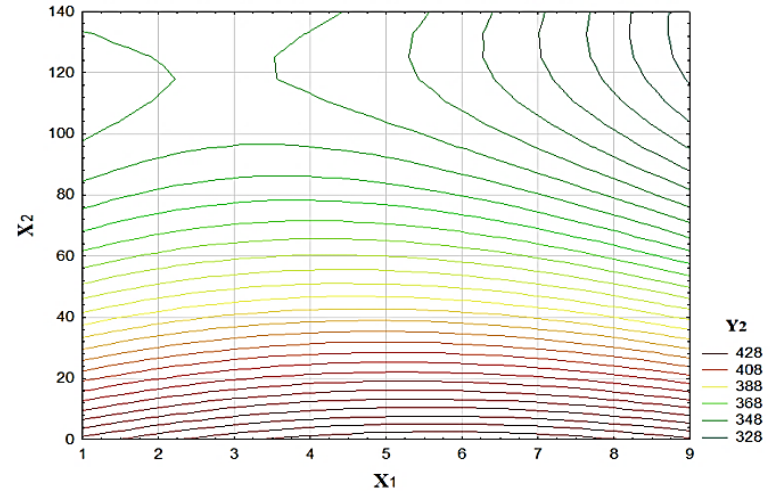

Fig. 8. Graph of the dependence of the extraction of rhodanide $Y_{2}$ on adsorbent dose $X_{1}$ and the purification time $X_{2}$, equation (6)

The obtained regression equations adequately describe the results of the experimental studies, the average relative error of the equations and their standard deviation lie within acceptable chemical technology limits.

The optimal glauconite dose in combination with the cationic flocculant in the amount of $5 \mathrm{ml} / \mathrm{dm}^{3}$ according to the first model of purification of phenolic wastewater is $2-6 \mathrm{~g} / \mathrm{dm}^{3}$ at a time duration of $110-140 \mathrm{~min}$, which leads to a decrease in the concentration of phenols from 510 to $330-390 \mathrm{mg} / \mathrm{dm}^{3}$.

According to the second model, the maximum degree of extraction of rhodanides is achieved at glauconite dose $2-3.5 \mathrm{~g} / \mathrm{dm}^{3}$ in combination with a cationic flocculant volume of $5 \mathrm{ml} / \mathrm{dm}^{3}$ and a time interval of $120 \mathrm{~min}$, which leads to a decrease in the concentration of rhodanides from 475.2 to $328-348 \mathrm{mg} / \mathrm{dm}^{3}$.

The results of the research allow us to recommend a natural mineral of glauconite with a minimum dose of $2 \mathrm{~g} / \mathrm{dm}^{3}$ with the addition of a cationic flocculant volume of $5 \mathrm{ml} / \mathrm{dm}^{3}$ for cost-effective provision of efficient wastewater treatment of coke production from phenols and rhodanides.

In the future, it is planned to carry out research on the further study of the mechanism of the process of adsorption-flocculation extraction of phenols with optimal dose selection of the cationic flocculant of polyacrylamide, regulated for industrial introduction at coke ovens.

In the world practice, sludge contaminated with various hydrocarbons that are formed during the purification of sediment which in its turn accumulates in the processing of resinous waste is used by asphalt plants. The experience is still poorly researched, but given the considerable similarity in the chemical properties of the pollutants this way of disposal of the substance should be considered possible, which is planned to be carried out in the following experiments.
References.

1. Onishchenko, G. G. (2015). Actual tasks of hygienic science and practice in maintaining public health. Hygiene and sanitation, (3), 7-11.

2. Kulikova, D. V., \& Pavlychenko, A. V. (2016). Estimation of ecological state of surface water bodies in coal mining region as based on the complex of hydrochemical indicators. Naukovyi Visnyk Natsionalnoho Hirnychoho Universytetu, (4), 62-70.

3. Klymenko, I., Yelatontsev, D., Ivanchenko, A., Dupenko, O., \& Voloshyn, N. (2016). Developing of effective treatment technology of the phenolic wastewater. Eastern-European Journal of Enterprise Technologies, 3(10(81)), 29-34. https:// doi.org/10.15587/1729-4061.2016.72410.

4. Alexandros Stefanakisa, I., Seegera, E., Dorerb, C., Sinkec, A., \& Thullnera, M. (2016). Performance of pilot-scale horizontal subsurface flow constructed wetlands treating groundwater contaminated with phenols and petroleum derivatives. Ecological Engineering, 95, 514-526. https://doi. org/10.1016/j.ecoleng.2016.06.105.

5. Polymeric materials: products, equipment, technologies (2019). Moscow: The concept of communication of the XXI century, 1999, (10), 68. Retrieved from https://rucont.ru/efd/667858. 6. Ivanchenko, A. V., Yelatontsev, D. O., Voloshin, M. D., \& Dupenko, O. O. (2015). Study of the technology of extracting resinous substances from wastewater from coke-chemical enterprises by the method of reagent flotation. Bulletin of Odessa Polytechnic University, 1(45), 158-163.

7. Kolesnyk, V.Ye., Kulikova, D.V., \& Pavlychenko, A.V. (2016). Substantiation of rational parameters of perforated area of partitions in an improved mine water settling basin. Naukovyi Visnyk Natsionalnoho Hirnychoho Universytetu, (6), 120-127.

8. Ivanchenko, A. V., \& Khavikova, K. Ye. (2019). Complex purification of industrial phenolic wastewater from virgin adsorbents from natural raw material. Bulletin of Vinnitsa Polytechnic Institute, (2), 27-34. https://doi.org/10.31649/19979266-2019-143-2-27-34.

9. Kharkina, O. V. (2015). Effective operation and calculation of biological wastewater treatment facilities. Volgograd: Panorama. ISBN 978-5-9666-0172-0.

10. Farberova, E.A., Tingaeva, E.A., \& Kobeleva, A.R. (2015). Sludge treatment using charcoal activated carbon waste. All-Russian scientific and practical journal. Water: chemistry and ecology, (6), 51-54.

11. Feofanov, Ryakhovsky, M. S. (2015). Comparative assessment of sorption capacities of homogeneous and complex loads during water treatment. All-Russian scientific and practical journal. Water: chemistry and ecology, (7), 85-90.

12. Somin, Betts S. A., \& Komarova, L. F. (2016). The use of crop waste in the purification of water from phenol. All-Russian scientific and practical journal. Water: chemistry and ecology, (4), 50-55. 13. Ganziuk, A. Ya., Karvan, S. A., \& Deychuk, G. M. (2016). Application of mineral adsorbents in the processes of purification, separation and conditioning of gas and liquid media. Bulletin of Khmelnitsky National University, (2), 266-269.

14. Fatima Zohra Choumane, Belkacem Benguella, Maachou, B., \& Saadi, N. (2017). Valorisation of a bioflocculant and hydroxyapatites as coagulation-flocculation adjuvants in wastewater treatment of the steppe in the wilaya of Saida (Algeria). Ecological Engineering, 107, 152-159. https://doi. org/10.1016/j.ecoleng.2017.07.013.

\section{Математичне моделювання процесів очищення стічних вод від фенолів і роданідів із використанням глауконіту}

\section{А. В. Іванченко, К. Є. Хавікова, А. І. Трикіло}

Дніпровський державний технічний університет, м. Кам'янське, Україна, е-mail: karina.havikova@gmail.com 
Мета. Підібрати оптимальну дозу природного мінералу глауконіту в поєднанні з катіонним флокулянтом для вилучення фенолів і роданідів із промислових стоків. Обгрунтувати переваги використання природного глауконіту як адсорбенту з розвиненою катіонною здатністю до поглинання токсичних речовин. Розробити математичну модель адсорбційного очищення фенольних стічних вод на флотаційній установці.

Методика. Хімічні дослідження здійснювали згідно з методиками В.М. Кагасова, С. К. Дербишевої. При проведенні експериментів із визначення концентрації фенолів у промислових стоках застосовували фотометричний метод, заснований на утворенні забарвлених у червоний колір з'єднань фенолів із 4-аміноантипірином у присутності гексаціаноферрату калію. Для встановлення концентрації роданідів у фенольній стічній воді використовували фотометричний метод, заснований на взаємодії роданід-іона в кислому середовищі з іонами заліза (III) хлориду. Визначення оптичної щільності розчинів проводили на фотоколориметрі концентраційному КФК-2 3 подальшим застосуванням калібрувальних графіків.

Результати. Експериментально показано, що при застосуванні інтервалу доз глауконіту 2-6 г/дм ${ }^{3}$ досягається найефективніше очищення рідких відходів від фенолів i зменшення концентрації вихідної фенольної води з 510 до $330-390$ мг/дм³ упродовж 110-140 хв на механічній стадії. Досягнуто зниження гранично допустимої концентрації (ГДК) фенолів у вихідних стічних водах коксохімічного підприємства, що регламентується - не більше 415 мг/дм ${ }^{3}$. Досліджено процес очищення промислових стоків від роданідів з підбором оптимальної дози адсорбенту за допомогою математичної обробки експериментальних даних, що склав 2-3,5 г/дм ${ }^{3}$ за тривалості флотації 120 хв. Отримане зниження вихідної концентрації роданідів із 475,2 до 328-348 мг/дм ${ }^{3}$. Досягнуто ГДК роданідів при нормі - не більше 400 мг/дм ${ }^{3}$ перед біологічним очищенням.

Наукова новизна. Досліджено процес сорбційного видалення фенолів і роданідів із рідких відходів з різними дозами глауконіту для опису математичної моделі адсорбційного процесу. Уперше встановлені кінетичні закономірності процесу вилучення фенолів зі стічних вод глауконітом у кількості 2-8 г/дм ${ }^{3}$ у поєднанні з катіонним флокулянтом об'ємом 5 мл/дм³ в інтервалі часу 20-120 хв, що дає можливість прогнозувати оптимальну дозу адсорбенту, вплив часу на сорбційний процес і знизити вміст забруднюючих агентів до екологічно безпечних показників.

Практична значимість. Надано математичний опис процесу очищення фенольних стічних вод із використанням глауконіту. Виходячи з опису математичної моделі, для промислового впровадження запропоновано використовувати природний адсорбент глауконіт в інтервалі оптимальних доз 2-6 г/дм ${ }^{3}$ у поєднанні з катіонним флокулянтом у кількості 5 мл/дм ${ }^{3}$ за оптимальної тривалості адсорбційного процесу 110-140 хв.

Ключові слова: коксохімічні стоки, адсорбція, феноли, роданіди, природний глауконіт, катіонний флокулянт

\section{Математическое моделирование процессов очистки сточных вод от фенолов и роданидов с использованием глауконита}

\author{
А. В. Иванченко, К. Е. Хавикова, А. И. Трикило
}

Днепровский государственный технический университет, г. Каменское, Украина, e-mail: karina.havikova@gmail.com
Цель. Подобрать оптимальную дозу природного минерала глауконита в сочетании с катионным флокулянтом для извлечения фенолов и роданидов из промышленных стоков. Обосновать преимущества использования природного глауконита как адсорбента с развитой катионной способностью к поглощению токсических веществ. Разработать математическую модель адсорбционной очистки фенольных сточных вод на флотационной установке.

Методика. Химические исследования осуществляли согласно методикам В. М. Кагасова, Е. К.Дербишевой. При проведении экспериментов по определению концентрации фенолов в промышленных стоках применяли фотометрический метод, основанный на образовании окрашенных в красный цвет соединений фенолов с 4-аминоантипирином в присутствии гексацианоферрата калия. Для установления концентрации роданидов в фенольной сточной воде использовали фотометрический метод, основанный на взаимодействии роданид-иона в кислой среде с ионами железа (III) хлорида. Определение оптической плотности растворов проводили на фотоколориметре концентрационном КФК-2 с последующим применением калибровочных графиков.

Результаты. Экспериментально показано, что при применении интервала доз глауконита 2-6 г/дм ${ }^{3}$ достигается эффективная очистка жидких отходов от фенолов и уменьшение концентрации исходной фенольной воды с 510 до $330-390$ мг/дм ${ }^{3}$ в течение 110-140 мин на механической стадии. Достигнуто снижение предельно допустимой концентрации (ПДК) фенолов в исходных сточных водах коксохимического предприятия, регламентируемое - не более 415 мг/дм³. Исследован процесс очистки промышленных стоков от роданидов с подбором оптимальной дозы адсорбента с помощью математической обработки экспериментальных данных, который составил 2-3,5 г/дм ${ }^{3}$ с продолжительностью флотации 120 мин. Получено снижение исходной концентрации роданидов с 475,2 до 328-348 мг/дм ${ }^{3}$. Достигнута ПДК роданидов при норме - не более $400 \mathrm{мг} /$ дм $^{3}$ перед биологической очисткой.

Научная новизна. Исследован процесс сорбционного удаления фенолов и роданидов из жидких отходов с различными дозами глауконита для описания математической модели адсорбционного процесса. Впервые установлены кинетические закономерности процесса извлечения фенолов из сточных вод глауконитом в количестве 2-8 г/дм ${ }^{3}$ в сочетании с катионным флокулянтом объемом 5 мл/дм ${ }^{3}$ в интервале времени 20-120 мин. Получена возможность прогнозировать оптимальную дозу адсорбента, влиять на время сорбционного процесса и снизить содержание загрязняющих агентов до экологически безопасных показателей.

Практическая значимость. Дано математическое описание процесса очистки фенольных сточных вод с использованием глауконита. Исходя из описания математической модели, для промышленного внедрения предложено использовать природный адсорбент глауконит в интервале оптимальных доз 2-6 г/дм ${ }^{3}$ в сочетании с катионным флокулянтом в количестве 5 мл/дм ${ }^{3}$ при оптимальной продолжительности адсорбционного процесса 110-140 мин.

Ключевые слова: коксохимические стоки, адсорбция, фенолы, роданиды, природный глауконит, катионный флокулянт

Recommended for publication by M.D. Voloshyn, Doctor of Technical Sciences. The manuscript was submitted 10.12.19. 